\title{
The Influence of Network Information Technology upon Management of China's Tertiary Institutions
}

\author{
Xue-Li DU ${ }^{1, a}$ \\ ${ }^{1}$ Institute of ideological and political education, North China University of W ater Resources \\ and Electric Power, Zhengzhou, 450046, China \\ aduxueli6@163.com
}

Key words: Network information technology, Tertiary Institutions, Management, Influence.

\begin{abstract}
Network information technology is transforming the management thought and style of China's tertiary institutions in a revolutionary way, which not only has a positive impact, but also has a negative impact. Therefore, the in-depth study on its influence and a clear understanding of its strengths and weaknesses can help us improve management efficiency and level of tertiary institutions.
\end{abstract}

\section{Introduction}

With the rapid development of modern information technology, especially with the wide spread of Internet in our daily life, human beings are entering a Network era. Internet is a great influential communication media with a large amount of audience and a strong impact, whose development will completely change not only the life pattern of human beings, but also their study and living style. Network means a revolution. In the face of the Network Revolution, how should the institutions of higher learning deal with it, what role should it play, these are new topics. The network information technology is affecting university's education idea, teaching idea and talents training mode, as well as the management system and operation mechanism of colleges and universities. Furthermore, the popularity and penetration of the Internet pose a challenge, and also an opportunity for the management mechanism reform and management mode to the colleges and universities. Should the management of colleges and universities be compatible with modern development process, tertiary institutions must be active to adopt modern information technology, especially network information technology, and realize the modernization of management methods, so as to raise the management level of colleges and universities. Therefore, it is necessary for us to study the impact of network information technology on the college management for the first.

\section{Colleges and university management has its certain particularity.}

From the structure of its organization, colleges and universities has the characteristics of disciplinarily and internationalism, which means that it has unusual management organization with academic openness, forward-looking and global knowledge, this makes it own a strong basis in the use of network information technology, and more positive in practice. From the point of managing content, colleges and universities, sets the party, administration, teaching, education, scientific research, development, teaching personnel, logistics service at a suit, with various management target, heavy management task, and the characteristic of diversity and complexity. From the point of management object, teachers and students are the main bodies of colleges and universities, they have higher degree and active thoughts, and stronger individual personality, with high intelligence and relative independence, these factors are certain increase the difficulty of colleges and universities management.

The network information technology helps the university carry out scientific and democratic decision-making, improve the transparency of management.

Abolishing the will of chief executives, consciousness of ranking, will actually reflect the cultural taste of modern university management. Since the founding of new China, management system of 
colleges and universities has made an enormous change, and the achievement can not be ignored, but bureaucracy, entrenched ranking are deeply rooted and hard to change, because of the influence of China's feudal autocracy and the authoritarian political, planned economy model of Soviet union, Weak consciousness of scientific and democratic decision-making, low level of the open, disclosure and transparent management fundamentally restricts the management of colleges and universities. So colleges and universities should advocate the following idea of management, such as science and democracy, people-oriented, knowledge and talent respected, emphasis on scientific decisionmaking, democratic style of work, which is the basic idea of modern university management. Computer network is a real-time, interactive information system. Everyone is not only the audience but also the transmitter of communication, who is free and easy to spread all kinds of information, and also autonomously accept various kinds of information in real time. In fact, staff and students in colleges and universities are active groups' access to the information network. With the aid of information network, they can get a lot of information outside, they often take it as the reference coordinates and make contrast study of their learning, working and lives. In addition, they express their point of views on the Internet, which sometimes becomes a hot topic in the campus, causing widespread concern. As to the management ranks of colleges and universities, it is better for them to provide wide opportunities for airing views actively rather than jam negatively. Furthermore, they can take advantage of campus network to issue all kinds of information which are concerned by staff and students, and collect different ideas and opinions in all aspects timely.

\section{The network information technology helps the university to establish management information processing system, change its original working mode, save time and manpower, and improve the efficiency of management.}

Computer network is a kind of modern information processing tools, which can make automatic, high-speed, precise information processing, storage, transfer and output, it has been fully used in the field of management, and greatly improve the management efficiency and level. The special status of university determines its high degree of network. Therefore, Network technology will be more productive for colleges and universities to improve their efficiency of management. Generally speaking, most universities have established management information processing system, which makes it possible for them to provide management data and information timely and completely, and makes decision-making process more scientific and accurate, so the evaluation system, information feedback will be more quickly. Due to the standardized and formatted information provided by network system, the time of data statistics, business transaction will be greatly reduced, it will not only reduce the manual labor, but also human errors, which results to the lower cost of management, and high working efficiency. Network information technology used in the management of colleges and universities has established a good foundation to realize the modernization of comprehensive management for universities. Office information system applied to the school and office management has greatly changed the school and administrative office mode, all kinds of notices, report forms can be easily transmitted through internet, which saved not only the time but also the energy. Leaders can learn about the dynamic information of the university at any time by campus network, they can also have direct communication with teachers and students through e-mail conveniently. Since the implement of computer management, the member of authority management is greatly reduced, and the management functions, service function got a new development. Thus, networked management in universities not only changed the original operating mode, but also greatly improved the working efficiency.

The network information technology helps to promote the administrative affairs of university open, to strengthen the supervision of public opinion, to improve the relations with the masses, to promote the construction of clean government, to improve the management style.

Colleges and universities should adhere to the correct political direction, grasp the right guidance of public opinions, and still insist on the socialist democracy, implement the idea of people-oriented, fully listen to the public opinions, and have a close connection with the masses. In colleges and universities, leaders, teachers, staff, and students, generally care about politics, concerned about 
social livelihood of the people, they commonly have strong sense of democracy consciousness and a much more deep thinking, which are quite significant for the construction and development of the universities. But managers in universities still have a certain degree of bureaucracy, because of the influence of the far-left ideological trend, and penetration of negative ranking ideas, which made it impossible to hear, to listen to the public opinions, and had a bad influence on work. With the popularity of computer networks, teachers and students in universities can get the latest information through various ways, and the consciousness of the right to know are more intense and conscious. So it is very important for universities to strengthen the construction of the Party conduct and of an honest and clear government, to promote the democratization process of management in colleges and universities. Generally, there are campus network in colleges and universities. managers can fully understand the condition of the teachers and students, public opinions, worry about what the masses of people are anxious about, think what they are thinking, maintain close ties with the masses with the help of the campus net BBS, chat rooms, or online survey column. They can also use campus network to expand their vision of decision-making, draw on the wisdom of the masses after the comparison and identification, and then choose and follow what is right, in order to avoid randomness and blindness of decision-making, which reflected the managers' leadership, also reflects the management concept of the masses. They can also fully mobilize the enthusiasm of all the teachers, students and staffs, and cooperate well with them to do a good job with the great efforts of everyone. Campus network is also a channel to carry out the supervision by public opinion. On the campus network, teachers, students and staffs can put forward criticism, report the real problem, these are unavoidable pressure from public opinion for managers, which would draw their attention to solving the problem or correcting their mistakes as soon as possible. On the campus network, teachers, students and all the staffs can still conduct public opinion polls about the satisfaction of the administrative departments and managers, and combine public opinion polls and the personnel appraisal result together, and actually play its important role of supervision by public opinion. Computer network creates a good public administrative work platform, various working system and procedures can be open on campus network, which is very convenient for the masses to deal with various things, and also convenient for them to conduct supervision. Some sensitive problems, such as purchase, promotion, rewards and punishment, also can be conducted openly, fairly, which will greatly reduce the opportunities for few managers to be corrupt. At the same time, set up the positive image of the management team in colleges and universities, and promotes the construction of the Party conduct and of an honest and clear management in universities, greatly improve the management style of colleges and universities.

\section{In general, the influence of network information technology on the management of colleges and universities is positive.}

Everything in the world has its advantages and disadvantage, the network information technology also has its negative effects on the university management, and its negative influence is relatively large, because of the high degree of network in tertiary institutions. Therefore, colleges and universities should attach great importance to managers in tertiary institutions.

\section{There are enormous bad information on the Internet}

Information on line transmits fast, and has a great influence, which are bound to have pollution on campus. Computer networks are by no means a piece of pure land, which is filled with all sorts of false information, bad information, and affects the physical and mental health of the university students.

The characteristics of Internet: globalization, no borders, interactivity, etc, to some extent, will also impact the internal relative independence in colleges and university of our country

The self-centered independence will weaken the internal cohesion of the university. Internet has fostered the global concept, open consciousness of staff and students in colleges and universities, therefore, Internet will effectively overcome their conservative, closed features, meanwhile, will 
also affect their sense of identity of school staff and students, enhance their sense of extroversion and centrifugal force, and affected the relative independence of colleges and universities, and add to the impetuous mood within the campus, which is not conducive to the studying and learning of teachers and students, and also weakens the charisma and cohesion of the school. Therefore, how to cultivate school's charisma and cohesion under the new circumstances is a major issue for managers in tertiary institutions at present time.

\section{Summary}

In the Internet age, people who refused the network will be refused by the world, who missed the network will miss the time. Whether you like it or not, the network information technology has fully accessed to our lives, and is constantly changing our world. Therefore, we have no other choice but to catch up with it, in addition, we must look at the network information technology with a cool eye, explore actively, and make further study of its positive influence, in order to give full play to its function and utility; For its negative influence, we must keep a clear mind, increase the sense of alertness, estimate its serious consequences, and make an active study of it, never sit and wait, never shy away from it, we should make the right response and proper disposal as soon as possible.

\section{References}

[1] Tsinghua university. To establish management system and operational mechanism, at the beginning of the 21 st century, in university [J]. Journal of tsinghua university education research, 1999, 1 (2).

[2] Maorong, LiuYi-heng. Institutions of higher learning management [M]. Nanjing: nanjing university press, 1997. P106.

[3] Guo Liying. The influence of online chat on college students' ideological and political education and its countermeasures $[\mathrm{J}]$. Journal of party construction and the ideological and political education, 2007 (9) : 45-46.

[4] Bai Xian-liang. The unique character of recessive ideological and political education [J]. Journal of party construction and the ideological and political education, 2007 (9) : 11-13.

[5] Yu Hui-qiong. The characteristics and intervention strategies of college students' network public opinions [J]. Journal of party construction and the ideological and political education, 2007 (3) : 42 44. 